\title{
PENGARUH PENGGUNAAN HEEL PAD TERHADAP DERAJAT NYERI PADA PENGGUNA HIGH HEELS
}

\author{
Sysbania, Yopi Harwinanda Ardesa, Muhammad Syaifudin \\ Kementerian Kesehatan Politeknik Kesehatan Surakarta Jurusan Ortotik Prostetik \\ Diterima : 11 Oktober 2018, Disetujui : 18 Oktober 2018
}

\begin{abstract}
Background : Along with the development of technology, increasing the industrial era in Indonesia cause a large number of companies, factories and malls are appeared to support the movement of the economy. Sales Promotion Girl (SPG) is one of the jobs that appear due to the proliferation of mall in a major city. The workers of this profession are typically women who have interesting physical character as an attempt to attract the attention of consumers. One of the performance standard is set by the company is wearing high heels and looking interesting. Methods : this study was carried out in 17 May - 1 June 2017 in PT. Matahari Department Store Solo Square by using quasi eksperimental methods with one group pre test and post test design. The number of samples are 20. Results : the results of this research are descriptive from 20 samples have already weared heel pad there is $80 \%$ of light pain scale and $20 \%$ of moderate pain scale, where before wearing heel pad there is $10 \%$ of light pain scale, $75 \%$ of moderate pain scale and $15 \%$ of severe pain scale. The research is the analysis based on the results of the analysis of the data obtained that value of wilcoxon test is 0,000 where the $P<0,05$. Conclusion : from the results of the research is there is the influence of the wear of the heel pad against the pain degree of the high heels wearers.
\end{abstract}

Keywords : Heel Pain, High Heels, Heel Pad, Pain Degree

\section{PENDAHULUAN}

Seiring dengan berkembangnya teknologi, semakin meningkatnya era industri di Indonesia menyebabkan banyaknya perusahaan - perusahaan, pabrik - pabrik dan mall - mall yang bermunculan untuk mendukung pergerakan perekonomian. Di zaman sekarang banyak diperlukannya sumber daya manusia untuk menunjang pekerjaan di perusahaan, pabrik dan mall tersebut. Manusia merupakan aset hidup yang perlu dipelihara dan dikembangkan.

Sales Promotion Girl (SPG) adalah salah satu pekerjaan yang muncul akibat menjamurnya mall - mall di kota besar. Profesi ini biasanya menggunakan wanita yang mempunyai karakter fisik yang menarik sebagai usaha untuk menarik perhatian konsumen. Penampilan seorang SPG yang ditentukan dari standar performa perusahaan itu berbeda-beda, dan dalam upaya memenuhi kebutuhan untuk tampil menarik konsumen, perusahaan menetapkan standar performa untuk SPG yaitu antara lain kerapian rambut, riasan wajah, kebersihan tubuh, dan menggunakan atribut perusahaan yaitu seragam dengan kelengkapan lain yaitu menggunakan sepatu hak tinggi atau yang sering disebut high heels (Poerwodarminto, 1987).

Karyawan yang bekerja dalam posisi berdiri lebih dari 6 jam per hari dan 
menggunakan high heels yang terlalu lama, akan membuat bagian tubuh terutama kaki mengalami gangguan akibat aktivitas menggunakan high heels tersebut. High heels juga dapat mengundang masalah pada lutut dan punggung, berisiko mengakibatkan cidera akibat terjatuh, memperpendek otot betis, penegangan otot, nyeri otot dan membuat cara berjalan pemakainya menjadi kurang nyaman, serta dapat mengakibatkan perubahan yang membuat fungsi kaki berkurang. Sebagian besar wanita pun mengakui bahwa pemakaian high heels menyebabkan nyeri pada kaki (Michael, 2012).

Memakai high heels di atas lima sentimeter membuat kaki terus-menerus jinjit. Hal ini menyebabkan otot betis yang berada di tumit belakang dalam keadaan tegang karena kontraksi otot yang terus menerus sehingga terjadi peningkatan ketegangan serabut otot dan menimbulkan stres mekanis pada jaringan miofasial dalam waktu yang lama. Hal ini akan menstimulasi nosiseptor yang ada di dalam otot. Semakin sering dan kuat nosiseptor tersebut terstimulasi maka semakin kuat refleks ketegangan otot, kemudian terjadi mikro sirkulasi yang tidak kuat, sehingga jaringan mengalami kekurangan nutrisi dan oksigen, yang dapat menimbulkan iskemik jaringan lokal serta menumpuknya zat-zat sisa metabolisme. Keadaan ini akan merangsang ujung-ujung saraf tepi nosiceptif tipe $\mathrm{C}$ untuk melepaskan suatu neuro peptide, yaitu $\mathrm{P}$ Subtance, dengan demikian, pelepasan tersebut membebaskan prostaglandin dan diikuti juga dengan pembebasan bradikinin, potassium ion, serotonin yang merupakan noxius atau chemical stimuli. Sehingga dapat menimbulkan nyeri.

\section{METODE PENELITIAN}

Pada penelitian ini menggunakan jenis penelitian quasi eksperimental dengan rancangan one group pre test and post test desain, dengan tujuan untuk mengetahui pengaruh penggunaan heel pad terhadap derajat nyeri pada pengguna high heels. Penelitian ini bersifat korelatif untuk mengetahui pengaruh satu kelompok pengguna high heels saat sebelum menerima perlakuan heel pad dan saat sesudah menerima perlakuan heel pad. Penelitian ini dapat digambarkan dengan pola sebagai berikut:

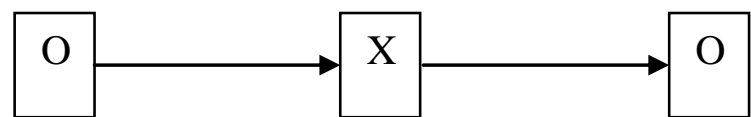

Gambar 3.1

Desain Penelitian

Keterangan gambar :

O1 : Kelompok sebelum diberi perlakuan

$\mathrm{X}$ : Perlakuan, yaitu pemberian heel pad

O2 : Kelompok sesudah diberi perlakuan

\section{HASIL PENELITIAN}

Subjek penelitian (sampel) dalam penelitian ini adalah Sales Promotion Girls (SPG) PT. Matahari Department Store Solo Square Surakarta yang memenuhi kriteria inklusi dengan karakteristik seperti pada Tabel 1 di bawah ini.

Tabel 1. Kriteria Inklusi Dengan Karakteristik

\begin{tabular}{ll}
\hline Karakteristik & \\
\hline Jumlah subjek & 20 subjek \\
Umur $\quad(20-30$ & Minimum : 20 tahun \\
tahun $)$ & Maksimum : 27 tahun \\
& Mean : 21,75 \\
Berat badan & Minimum : $38 \mathrm{~kg}$ \\
& Maksimum : $58 \mathrm{~kg}$ \\
& Mean : 48,20 \\
Tinggi badan & Minimum $: 148 \mathrm{~cm}$ \\
& Maksimum : $167 \mathrm{~cm}$ \\
& Mean $: 157,05$ \\
\hline
\end{tabular}


Berdasarkan Tabel 1 karakteristik subjek penelitian diketahui berjumlah 20 orang. Umur rata-rata 21,75 tahun, berat badan rata - rata $48,20 \mathrm{~kg}$ dan tinggi badan rata - rata $157,05 \mathrm{~cm}$.

Tabel 2. Skala Nyeri

\begin{tabular}{lll}
\hline Skala Nyeri (VAS) & Pre & Post \\
\hline a. nyeri ringan & $10 \%$ & $80 \%$ \\
b. nyeri sedang & $75 \%$ & $20 \%$ \\
c. nyeri berat & $15 \%$ & $10 \%$ \\
\hline \multicolumn{1}{c}{ Berdasarkan } & Tabel & 2
\end{tabular}

deskripstif dari 20 sampel yang sudah memakai heel pad terdapat $80 \%$ skala nyeri ringan dan $20 \%$ skala nyeri sedang, dimana sebelum memakai heel pad $10 \%$ skala nyeri ringan, $75 \%$ skala nyeri sedang dan $15 \%$ skala nyeri berat.

Perubahan nyeri diukur dengan Visual Analogue Scale (VAS), yang hasilnya merupakan data kontinu. Untuk mengetahui ada tidaknya perbedaan nilai VAS saat awal (pre) dan saat akhir penelitian (post), dilakukan analisis uji hipotesis Wilcoxon.

Sebelum data di analisis dengan uji Wilcoxon, terlebih dahulu di lakukan uji normalitas untuk memastikan bahwa data berdistribusi normal. Pada penelitian ini, hasil uji normalitas (uji Shapiro-Wilk) terhadap data nilai VAS diperoleh nilai $\mathrm{p}$ $=0,045$ dimana $p<0,5$ ini berarti data berdistribusi tidak normal.

Kemudian di uji pengaruh heel pad terhadap derajat nyeri menggunakan wilcoxon test, didapatkan hasil nilai derajat nyeri $\mathrm{p}=0,000$ dimana $\mathrm{p}<0,05$ yang berarti ada pengaruh derajat nyeri sebelum dan sesudah pemberian heel pad.

\section{PEMBAHASAN}

Dari hasil penelitian ini terlihat bahwa pemberian heel pad dapat menurunkan derajat nyeri pada pengguna high heels. Hasil uji statistik wilcoxon didapatkan nilai $\mathrm{p}=0,000$ dimana $\mathrm{p}<$ 0,05 . Sehingga dapat disimpulkan bahwa pemberian heel pad dapat menurunkan derajat nyeri secara signifikan antara derajat nyeri sebelum dan derajat nyeri sesudah pemberian heel pad pengguna high heels pada Sales Promotion Girls di PT. Matahari Department Store Solo Square Surakarta.

Hasil penelitian ini serupa dengan penelitian yang dilakukan oleh Faidah Satriana (2011), dimana hasil penelitian ini diuji Mann-Whitney, sehingga di dapat nilai $\mathrm{p}=0,017, \mathrm{p}<0,05$ yang berarti ada perbedaan yang sangat signifikan terhadap penambahan calcaneal pad pada intervensi ultrasound, longitudinal stretching terhadap pengurangan nyeri plantar fasciitis.

Hasil penelitian ini sejalan dengan penelitian Gross Et Al (2002), yang berjudul The Impact Of Custom Semirigid Foot Orthotics On Pain And Disability For Individuals With Plantar Fasciitis. Penelitian ini menggunakan cohort study menggambarkan $75 \%$ nyeri berkurang setelah 12 sampai 17 hari menggunakan custom semi-rigid orthosis. Sebanyak 15 subjek (8 laki - laki dan 7 wanita) yang berumur 18 tahun dan memiliki medial arch atau heel pain satu bulan sebelum dilakukannya penelitian. Subjek diminta memakai ortosis selama 12 sampai 17 hari selama jam kerja. Didapatkan hasil $66 \%$ mengurangi nyeri dan $75 \%$ mengurangi disability. Hasil uji wilcoxon didapatkan hasil yang signifikan $p=0,005$ dimana $p$ $<0,05$ yang berarti ada pengaruh yang signifikan saat sebelum dan sesudah pemberian intervensi berupa semi rigid orthosis.

Pemakaian high heels dalam waktu yang relatif lama dapat menyebabkan seseorang beresiko terjadi 
nyeri tumit. Hal ini disebabkan karena seseorang yang menggunakan high heels memaksakan kakinya untuk "jinjit". Posisi "jinjit" dalam kinesiologi biomekanik masuk dalam lever 2, yaitu resisten terletak diantara fulcrum dan gaya, dimana resisten selalu dekat dengan fulcrum.

Posisi berdiri statis dalam waktu yang lama menyebabkan fascia plantaris dan otot-otot disekitar telapak kaki dipaksakan untuk berkontraksi. Pada lever 2 tumpuan berat badan terjadi pada ujungujung ibu jari kaki yang berpengaruh besar pada fascia plantar. Ketika mulai melangkah otomatis fascia plantar mulai tertarik dan mempengaruhi arcus longitudinal. Keduanya saling kontraksi dan menegang sehingga terjadi peradangan.

Ditambah tumit dengan base yang sempit dan kecil pada fascia plantar menambah stres mekanis pada jaringan miofascial dalam waktu yang lama. Prevalensi yang terjadi pada penekanan bagian sepanjang ligament plantar fascia biasa disebut fasciitis plantaris.

Secara teoritis nyeri tumit yang disebabkan karena pemakaian sepatu hak tinggi dapat dikurangi dengan menggunakan heel pad. Heel pad dapat membantu memberikan shock absorption dan membantu mendistribusikan lebih baik tekanan pada foot. Saat tekanan sudah terdistribusi denga rata, maka nyeri pada heel akan berkurang (Seligman, 2003).

\section{KESIMPULAN DAN SARAN}

Berdasarkan hasil penelitian yang berjudul pengaruh penggunaan heel pad terhadap derajat nyeri pengguna high heels yang dilakukan pada Sales Promotion Girls di PT. Matahari
Department Store Solo Square Surakarta selama 2 minggu yang dimulai dari tanggal 17 Mei 2017 sampai 1 Juni 2017, dan melakukan pengukuran derajat nyeri menggunakan Visual Analog Scale (VAS). Dapat disimpulkan bahwa skala nyeri sebelum pemakaian heel pad yaitu nilai minimal 3 (nyeri ringan), nilai maksimal 9 (nyeri berat) dengan rata rata 5,15 (nyeri sedang), sedangkan skala nyeri setelah pemakaian heel pad didapatkan nilai minimal 1 (nyeri ringan), nilai maksimal 6 (nyeri sedang) dengan rata - rata 2,45 (nyeri ringan).

Uji pengaruh heel pad terhadap derajat nyeri menggunakan wilcoxon test karena data berdistribusi tidak normal dan didapatkan hasil nilai derajat nyeri $\mathrm{p}=$ 0,000 dimana $\mathrm{p}<0,05$ yang berarti ada pengaruh penggunaan heel pad terhadap penurunan derajat nyeri sebelum dan sesudah pemakaian heel pad sebesar $100 \%$.

Adapun saran yang dapat diberikan bagi peneliti yang ingin melanjutkan penelitian ini adalah agar menambahkan subjek penelitian dan juga memperhatikan faktor - faktor yang tidak terkontrol penyebab nyeri tumit seperti bentuk kaki flat foot atau high arch dan lama pemakaian high heels. Penelitian ini diharapkan juga bisa menambah khasanah pengetahuan mengenai intervensi nyeri tumit pada pengguna high heels berupa pemberian heel pad.

Disarankan bagi responden agar pada saat bekerja tidak hanya berdiri statis secara terus menerus tetapi juga melakukan gerakan dinamis seperti berjalan. Pada saat istirahat hendaknya melepas high heels dan menggantinya dengan sepatu tumit datar (flat shoes) atau sandal dan juga meluangkan waktu untuk 
melakukan latihan peregangan atau relaksasi walaupun hanya sebentar.

\section{DAFTAR RUJUKAN}

Ahira, Anne. 2012. Sejarah Sepatu: Dari Sepatu Kets Sampai Sepatu High Heels. Jakarta: Gagas Media.

Daniel, Weyne W. 2008. Statistika Nonparametrik Terapan. Jakarta: PT. Gramedia.

Gross M, Byers J, Krafft J, Lackey E, Melton K. 2002. The Impact of Custom Semirigid Foot Orthotics On Pain And Disability For Individuals With Plantar Fasciitis. J Orthop Sports Phys Ther

L.N. Michael. 2012. High Heels And Pain How To Prevent It.

Pfeffer, G. Bacchetti, P. Deland, J. Et Al.1999. Comparison Of Custom And Pre fabricated Orthoses In The Initial Treatment of Proximal Plantar Fasciitis. Foot Ankle Int.

Poerwodarminta. 1987. Kamus Umum Bahasa Indonesia. Jakarta: Balai Pustaka.

Seligman, D.A. 2003. Customized Heel Pads And Soft Orthotics To Treat Heel Pain And Plantar Fasciitis. American Congress Of Rehabilitation Medicine And The American Academy Of Physical Medicine And Rehabilitation, 1565. 